LAWRENCE LIVERMORE N A T IO N A L LABORATORY

\section{Evaluation and Optimization of MTBE Biodegradation in Aquifers, Final Report}

Tina Legler, Lianna Balser, Carolyn Koester, Wendy Wilson

February 17, 2004 
This document was prepared as an account of work sponsored by an agency of the United States Government. Neither the United States Government nor the University of California nor any of their employees, makes any warranty, express or implied, or assumes any legal liability or responsibility for the accuracy, completeness, or usefulness of any information, apparatus, product, or process disclosed, or represents that its use would not infringe privately owned rights. Reference herein to any specific commercial product, process, or service by trade name, trademark, manufacturer, or otherwise, does not necessarily constitute or imply its endorsement, recommendation, or favoring by the United States Government or the University of California. The views and opinions of authors expressed herein do not necessarily state or reflect those of the United States Government or the University of California, and shall not be used for advertising or product endorsement purposes.

This work was performed under the auspices of the U.S. Department of Energy by University of California, Lawrence Livermore National Laboratory under Contract W-7405-Eng-48. 


\section{SUMMARY}

This study was focused on meeting the following objectives concerning the process of methyl tertiary butyl ether (MTBE) biodegradation, with the goal of optimizing this process in situ:

1. Assess whether intrinsic bioattenuation of MTBE is feasible under aerobic conditions across several contaminated sites.

2. Determine the effect of co-contaminants, specifically water-soluble gasoline components (most notably benzene, toluene, ethylbenzene and xylenes [BTEX]) on MTBE biodegradation.

3. Determine whether microbial and/or chemical factors contribute to different MTBE degradative activities.

4. Isolate and characterize MTBE-degrading microorganisms from sediments in which MTBE biodegradation was observed.

The potential for aerobic methyl tert-butyl ether (MTBE) degradation was investigated in microcosms containing aquifer sediment and groundwater from seven leaking underground fuel tank (LUFT) sites characterized by anoxic in situ conditions. Relatively rapid MTBE depletion was observed for sediments from three sites (i.e., after variable lag periods of 4-19 days, $0.8 \mathrm{mg} \mathrm{MTBE} \mathrm{L}^{-1}$ day $^{-1}$ was removed), whereas, no consumption of MTBE was observed for sediments from the other sites after up to 350 days. For sediments lacking MTBE degradation activity, addition of MTBE-degrading microorganisms resulted in MTBE removal, whereas, addition of growth medium had no effect after 94 days. For sediments in which MTBE was consumed, approximately 50\% of added uniformly radiolabeled MTBE was mineralized to ${ }^{14} \mathrm{CO}^{2}$. Molecular phylogenetic analyses (Denaturing Gradient Gel Electrophoresis, DGGE) of these sediments indicated the enrichment of species closely related to a known MTBEdegrading bacterium, strain PM1, while these species were not detected in sediments lacking MTBE degradation activity. Real-time Polymerase Chain Reaction (PCR) analysis targeting PM1-like bacterial strains confirmed these findings. MTBE-degrading pure culture isolates were obtained from two of the three sites with MTBE degradation activity; in each case, the isolates were 98-99\% similar to PM1 based on 16S rDNA sequences. At only one of three sites, the presence of dissolved gasoline components, most notably BTEX (benzene, toluene, ethylbenzene and xylenes), significantly inhibited MTBE degradation and led to more pronounced accumulation of tert-butyl alcohol (TBA). Our results suggest that the effects of oxygen and dissolved gasoline components on in situ MTBE degradation are not consistent from site to site, and that phylogenetic analysis may have potential for predicting MTBE biodegradation activity.

\section{INTRODUCTION}

Contamination of drinking water supplies by the fuel oxygenate methyl tert-butyl ether (MTBE) has become a national concern due its widespread use in reformulated gasoline and the preponderance of leaking underground fuel tank (LUFT) sites. It has been estimated that 250,000 of the approximately 385,000 confirmed LUFT releases in the U.S. involve MTBE (Johnson et al., 2000), while in California more than 10,000 LUFT sites are estimated to involve MTBE (Happel et al., 1998). Although MTBE is being phased out as a gasoline additive, it is expected to continue to impact groundwater supplies for years to come because of its mobility in groundwater and recalcitrance to biodegradation. 
Recent laboratory and field experiments (e.g., Salanitro et al., 2000; Wilson et al., 2002) have shown that at least under aerobic conditions, MTBE is less recalcitrant than previously thought. While these results are promising, there is still insufficient information concerning MTBE biodegradation, especially regarding the distribution of aerobic MTBE degradation activity across LUFT sites. It is not clear whether adding oxygen to anoxic sediments at a given LUFT site will result in MTBE degradation in all cases. One objective of this work was to determine how widespread aerobic MTBE degradation is across sites with similar contamination histories and hydrogeological conditions. It is essential to establish the potential for intrinsic degradation in order to decide among remedial alternatives for treatment of MTBE-impacted sites and to formulate corrective-action regulatory guidelines for fuel hydrocarbon plumes containing MTBE. Technologies are under development for delivery of oxygen to the subsurface (Mackay et al., 2000) so that under some conditions, aerobic biodegradation of MTBE may be enhanced in situ.

In addition, the influence of other reformulated gasoline components on MTBE biodegradation in aquifer sediments has not been adequately addressed, although individual BTEX compounds were shown to inhibit MTBE degradation by strain PM1 (Deeb et al., 2001). In this paper, we discuss the effects of the presence of oxygen and water-soluble gasoline components on MTBE and TBA metabolism by aquifer bacteria from seven different LUFT sites. Furthermore, we investigated whether chemical or biological factors were limiting MTBE biodegradation and whether specific microbial communities were associated with MTBE degradation activity.

In this work, representative aquifer sample material and groundwater was obtained from LUFT sites, and microcosms were constructed and analyzed for MTBE and metabolites including TBA. Results from these studies were used to show the degradative potential of naturally-occurring aquifer microorganisms to effect bioattenuation of MTBE at LUFT sites. Furthermore, MTBE-degrading microorganisms were isolated and characterized for potential use in bioaugmentation and ex situ treatment of MTBE- and TBA-contaminated groundwater. The overall goal of this research is to better understand how MTBE is degraded in order to optimize aerobic MTBE biodegradation.

\section{MATERIALS AND METHODS}

Aquifer sediment and groundwater were obtained from seven MTBE-contaminated LUFT sites in northern California that were characterized by anoxic conditions (Table 1). Sediments for microcosm construction were chosen from 2-11 feet below the water table. MTBE concentrations in groundwater from associated sediments ranged from 200 to $5,200 \square \mathrm{g} / \mathrm{L}$ for MTBE and $<5$ to $13,500 \square \mathrm{g} / \mathrm{L}$ total BTEX. Groundwater was obtained from a well at the site that was non-detect for MTBE, TBA, or BTEX. Microcosms contained $15 \mathrm{~g}$ of wet sediment and $72 \mathrm{~mL}$ of groundwater in 125- $\mathrm{mL}$ amber glass,screw-cap bottles with Teflon-lined septa. For sterile microcosms, the sediments were autoclaved and sodium azide was added at $2 \mathrm{~g} / \mathrm{L}$. MTBE was added from 4-5 mg/L, and bottles were end-over-end mixed at room temperature. Microcosms were monitored for dissolved oxygen using a Lazar DO-166 Dissolved Oxygen Probe. For microcosms amended with water-soluble gasoline components, non-oxygenated gasoline was equilibrated with groundwater and gasoline-saturated groundwater was added to yield a starting BTEX concentration of approximately $1 \mathrm{mg} / \mathrm{L}$. For some experiments, groundwater was replaced with growth medium (Widdel et al., 1992). 
TABLE 1. Description of sites included in microcosm studies.

\begin{tabular}{|c|c|c|c|}
\hline Site Name & Sediment Description ${ }^{a}$ & $\begin{array}{c}\text { MTBE } \\
\text { concentration } \\
(\square g / L)\end{array}$ & $\begin{array}{c}\text { BTEX } \\
\text { concentration } \\
(\square g / L)\end{array}$ \\
\hline Palo Alto & $\begin{array}{l}\text { Split-spoon sample, } 175 \mathrm{ft} \text { down- } \\
\text { gradient of tank field, } 9.5-10 \text { ' bgs, WT } \\
\text { 7-8' bgs; sandy clay. }\end{array}$ & 1,200 & $<5$ \\
\hline Sacramento & $\begin{array}{l}\text { Split-spoon sample, } 20 \mathrm{ft} \text { down- } \\
\text { gradient of tank field, } 36-36.5 \text { ' bgs, } \\
\text { WT } 25^{\prime} \text { bgs, silty clay. }\end{array}$ & 2,000 & 2,500 \\
\hline Travis AFB & $\begin{array}{l}\text { Geoprobe sample, } 20 \text { '-25' down- } \\
\text { gradient of tank field, } 21-22 \text { ' bgs, WT } \\
8.5-9.5 \text { ' bgs, sandy clay. }\end{array}$ & 200 & 8,300 \\
\hline San Jose 1 & $\begin{array}{l}\text { Split-spoon sample, } 30 \text { ' down-gradient } \\
\text { of tank field, 17-18' bgs, WT <15' bgs, } \\
\text { silty clay. }\end{array}$ & 200 & $<5$ \\
\hline San Mateo & $\begin{array}{l}\text { Split-spoon sample, } 20 \text { ' down-gradient } \\
\text { of tank field, } 45.5-46.5 \text { ' bgs, WT } \sim 40^{\prime} \\
\text { bgs, silty clay. }\end{array}$ & 4,200 & 3,900 \\
\hline San Jose 2 & $\begin{array}{l}\text { Split-spoon sample, }<10^{\prime} \text { down- } \\
\text { gradient of tank field, } 18-18.5^{\prime} \text { bgs, } \\
\text { WT } \sim 15^{\prime} \text { bgs, silty clay. }\end{array}$ & 200 & 13,500 \\
\hline Millbrae & $\begin{array}{l}\text { Split-spoon sample, } 20 \text { ' down-gradient } \\
\text { of tank field, } 6-7 \text { ' bgs, WT < 5' bgs, } \\
\text { silty clay. }\end{array}$ & 5,200 & $<5$ \\
\hline
\end{tabular}

MTBE and TBA were analyzed over time by purge-and-trap gas chromatographymass spectrometry (GC-MS) with selected ion monitoring; analytical instrumentation included an Archon AutoSampler System interfaced to a Hewlett-Packard Model 5973 Mass Selective Detector fitted with a Restek Rtx-502.2 column. Internal standard quantification with MTBE- $d_{12}$ was used for MTBE and external standard quantification was used for TBA. The method detection limits were approximately $0.05 \square \mathrm{g} / \mathrm{L}$ for MTBE and $0.5 \square \mathrm{g} / \mathrm{L}$ for TBA.

Total community DNA was extracted and purified from microcosms and from enrichment cultures as described previously (Beller et al., 2002). 16S rDNA was amplified by the PCR using eubacterial universal primers f968/r1401 containing a 40-bp 5'-GC clamp (Weisburg et al., 1991). No-template and no-primer controls were analyzed on a $1 \%$ agarose gel to confirm the absence of PCR products. PCR reactions were run on a denaturing gradient gel (40-80\% gradient) after the method of Muyzer et al. (1993) using a BioRad D-Code apparatus. The DNA was extracted from bands, re-amplified, and sequenced; 16S rDNA sequences were searched against the NCBI GenBank database.

Pure culture isolates were obtained from enrichment cultures by sub-culturing on mineral salts agar plates containing MTBE. MTBE degradation activity was confirmed in liquid culture by GC/MS as described above. Genomic DNA was isolated using standard protocols (Ausubel et al., 1989) and the full length 16S rDNA sequence was amplified using primers 27f and 1492r (Lane, 1991). Amplicons were cloned using a TA cloning kit (Invitrogen) and sequenced and searched against the NCBI database. 


\section{RESULTS AND DISCUSSION}

Aerobic MTBE biodegradation results. In Palo Alto microcosms, MTBE was rapidly degraded in $\sim 15$ days after a lag period of about 4 days (Figure 1). When the microcosms were re-spiked, MTBE was degraded at a similar rate; however, TBA accumulated to $\sim 2$ $\mathrm{mg} / \mathrm{L}$ and persisted for 27 days. These data indicate that TBA can accumulate in sediment-water systems with environmentally relevant MTBE concentrations. A similar lag period and MTBE degradation rate $\left(0.8 \mathrm{mg} \mathrm{L}^{-1} \mathrm{day}^{-1}\right)$ was observed for Palo Alto sediments from approximately 150 ' down gradient from this location. When site groundwater was replaced with growth medium, MTBE degraded in only 7 days after a similar 4-day lag period.

While these data were promising for aerobic MTBE degradation potential, the results were not consistent across all LUFT sites tested (Table 2). MTBE biodegradation was rapid for sediments from three of the seven sites; after a variable lag period of 4-19 days, MTBE degraded at a rate of $\sim 0.8 \mathrm{mg} \mathrm{L}^{-1} \mathrm{day}^{-1}$ for all three sites. For the Palo Alto and Travis AFB sites, 43-54\% of added uniformly radiolabeled MTBE was converted to carbon dioxide (Kane et al., 2001). However, no MTBE degradation was observed in sediments from the other four sites even after 170 to 350 days, although the dissolved oxygen measurements showed that aerobic conditions were maintained throughout the course of the experiment.

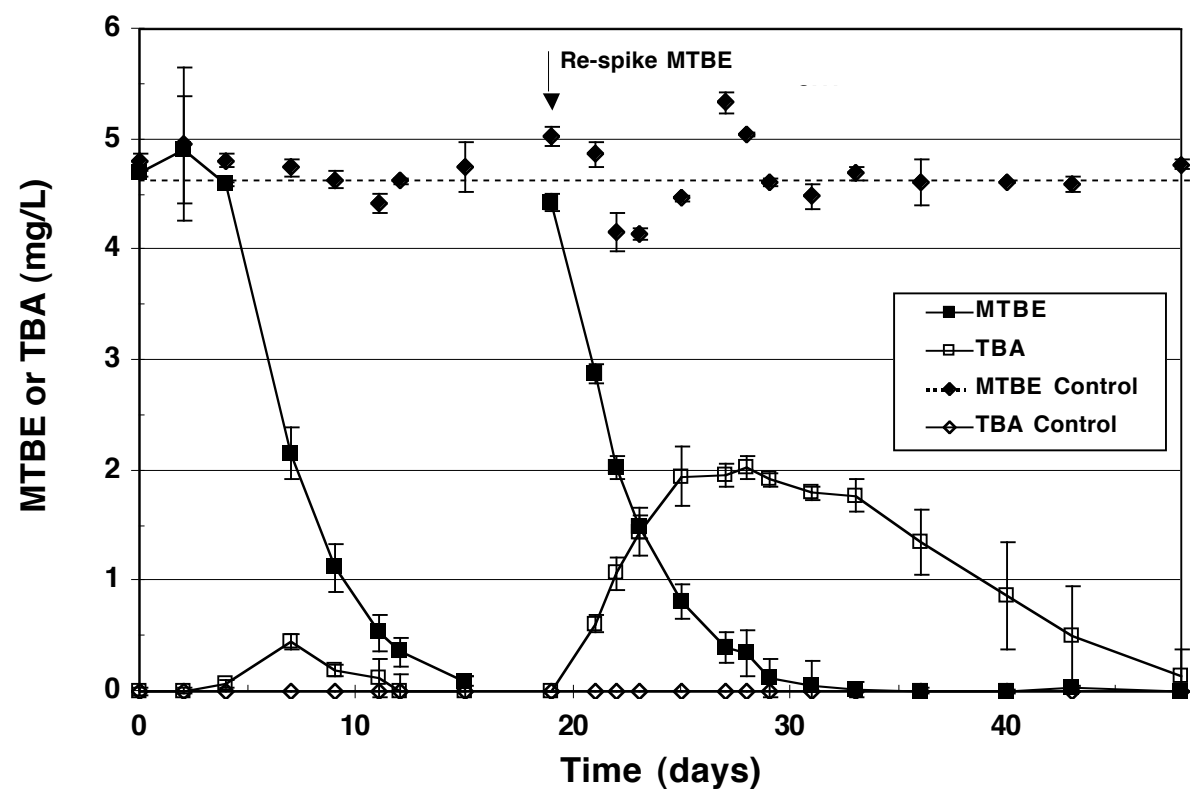

FIGURE 1. MTBE biodegradation in microcosms from Palo Alto sediments.

Based on these data, we initiated a study to determine whether MTBE degradation was limited by chemical (nutrient) factors or biological factors (i.e., MTBE- degrading microorganisms were either absent or in too low abundance). The sediment from the Millbrae live microcosms was harvested and split into three fractions (two replicates each). Fraction 1 was amended with fresh site groundwater, fraction 2 was amended with growth medium, and fraction 3 was amended with growth medium and inoculated with a highly-enriched MTBE-degrading mixed culture ( $\sim 13 \mathrm{mg} \mathrm{MTBE} \mathrm{L}^{-1}$ day $^{-1}$ degradation rate). All fractions were spiked with $4.5 \mathrm{mg} / \mathrm{L} \mathrm{MTBE}$ and monitored for MTBE and TBA over time as described above. For the first two fractions, there was no MTBE degradation after 94 days, whereas, for fraction 3, MTBE degradation began after 10 days and was 
completely degraded after 17 days. These data suggested that the limitation for MTBE degradation was likely biological rather than chemical.

TABLE 2. Summary of MTBE biodegradation data for seven LUFT sites tested.

\begin{tabular}{|c|c|c|}
\hline Site Name & $\begin{array}{c}\text { Time for MTBE } \\
\text { depletion (days) }\end{array}$ & $\begin{array}{c}\text { Lag period } \\
\text { (days) }^{\text {a }}\end{array}$ \\
\hline Palo Alto & $\sim 15$ & $\sim 4$ \\
\hline Sacramento & $>170$ & NA \\
\hline Travis AFB & $\sim 20$ & $\sim 10$ \\
\hline San Jose 1 & $>350$ & NA \\
\hline San Mateo & $\sim 27$ & $\sim 19$ \\
\hline San Jose 2 & $>200$ & NA \\
\hline Millbrae & $>350$ & NA \\
\hline
\end{tabular}

Microbial community structure analysis. Denaturing gradient gels of $16 \mathrm{~S}$ rDNA amplified from microcosms and enrichment cultures are shown in Figure 2 (panels A-C). In cases where microcosms were consuming MTBE (Palo Alto, Travis AFB and San Mateo sediments; panels A and C), a significant shift in the DGGE profiles from initial conditions (sterile controls) was evident. A dominant band (denoted by arrows) was present in these microcosms and in a highly-enriched mixed culture from Palo Alto sediments (Figure 2, panel A). In all profiles of active cultures, the DNA sequence of this band was 98-99\% similar to the Rubrivivax sp. strain PM1 (Hanson et al., 1999), a known MTBE-degrading bacterium. This band (and corresponding sequence) was not

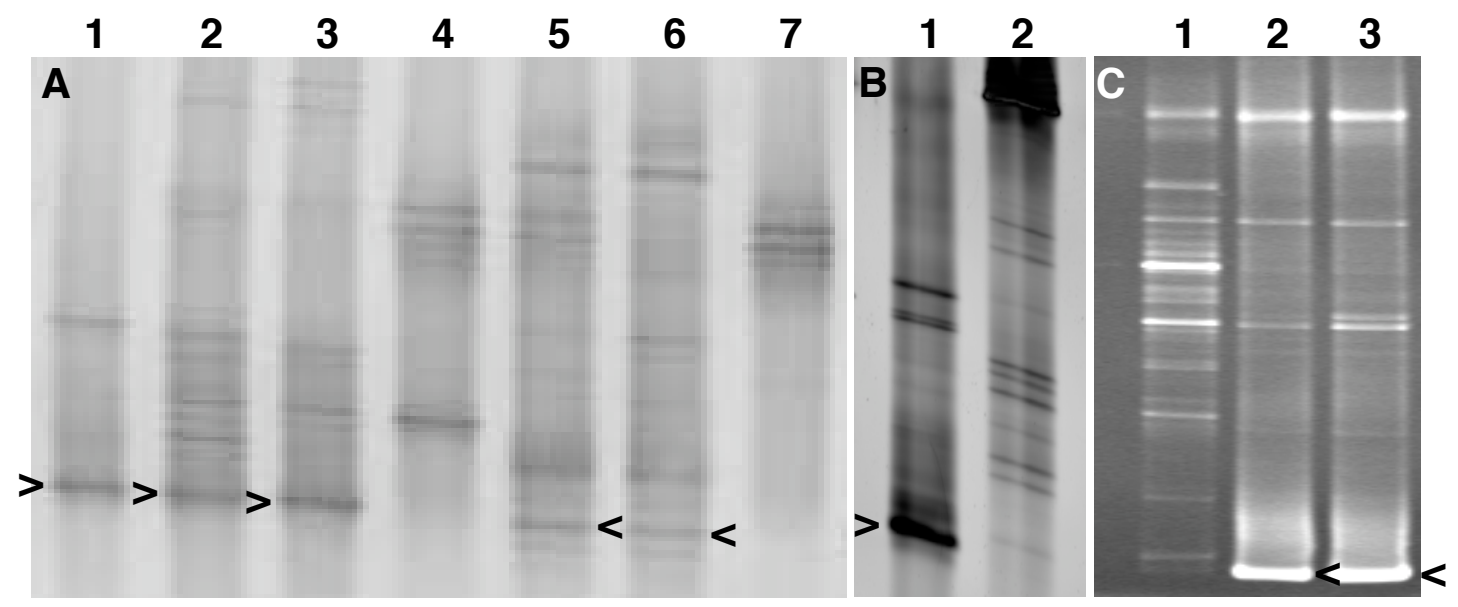

FIGURE 2. DGGE profiles from LUFT site microcosms and enrichment cultures. Arrows denote bands with sequences similar to the known MTBEdegrading strain PM1 (Hanson et al., 1999). (A) Lane 1, enrichment culture from Palo Alto sediments; Lanes 2 and 3, live microcosms from Palo Alto; Lane 4, sterile control for Palo Alto; Lanes 5 and 6, live microcosms from Travis AFB; Lane 7, sterile control for Travis AFB. (B) Lane 1, enrichment culture from Palo Alto sediments; Lane 2, live microcosm from Sacramento sediments. (C) Lane 1, sterile control for San Mateo; Lanes 2 and 3, live microcosms from San Mateo sediments. Panels A and B have inverted image intensities. 
present in control microcosms, suggesting that this strain was present at $<1 \%$ of the total indigenous population, the theoretical lower limit of detection for DGGE (Muyzer et al., 1993). Furthermore, a corresponding band was not present in a live Sacramento microcosm (Figure 2, panel B). Analysis of DNA extracts from microcosms using the real-time PCR method for PM1 (Hristova et al., 2002) showed that populations of PM1like bacteria were present in sediments with MTBE degradation activity (San Mateo and Travis AFB) and not present in San Jose 2 sediments that lacked activity (K. Hristova, personal communication).

Effects of dissolved gasoline components. The three sites that had MTBE degradation activity (Palo Alto, Travis AFB and San Mateo) were evaluated for the effect of dissolved gasoline components on MTBE degradation kinetics. For all three sites, BTEX compounds were degraded from $\sim 1 \mathrm{mg} / \mathrm{L}$ to non-detect in 1-3 days. Furthermore, MTBE at approximately 4-5 $\mathrm{mg} / \mathrm{L}$ did not inhibit degradation of any BTEX compound. However, there was a significant effect of dissolved gasoline components on MTBE degradation in the Palo Alto microcosms (Figure 3). MTBE degradation was slowed by about 10 days relative to samples without added gasoline components. The effect was more pronounced on TBA showing it accumulated to more than $1 \mathrm{mg} / \mathrm{L}$ and persisted for $>21$ days longer when gasoline components were added. This experiment was repeated two times with similar results. For the other sites, Travis AFB and San Mateo, there was

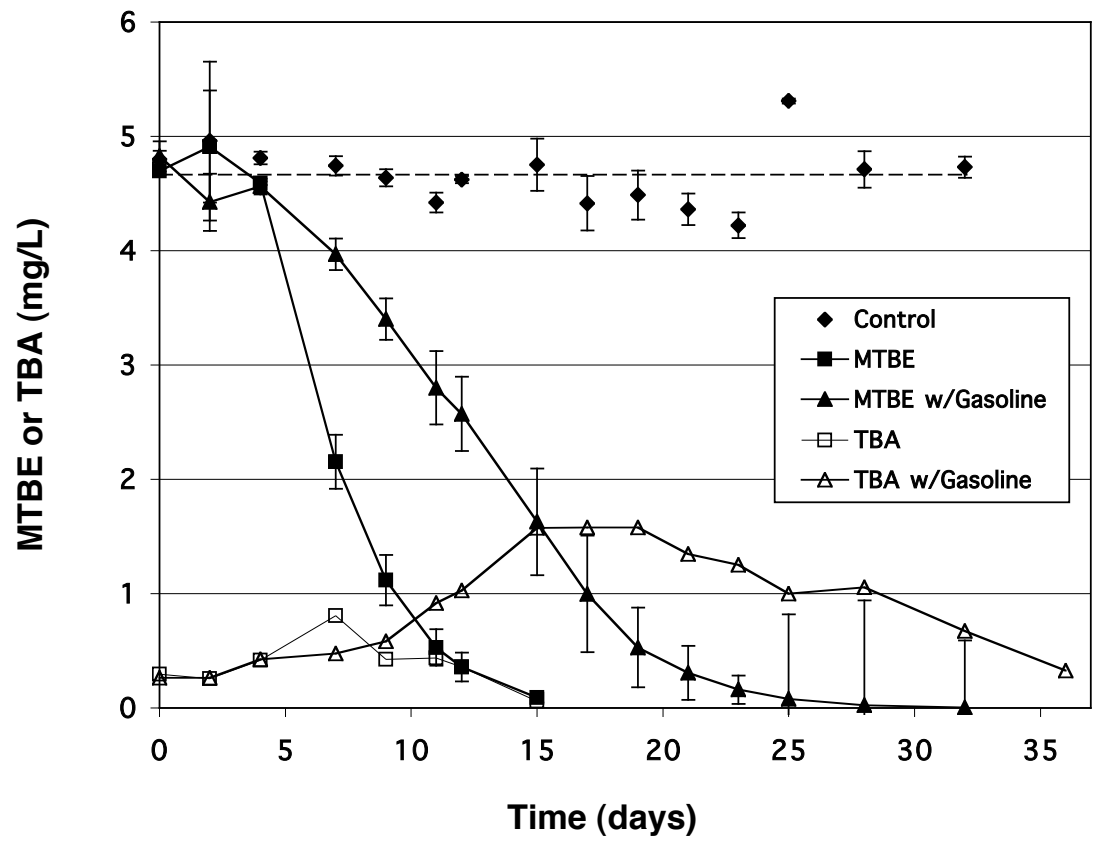

FIGURE 3. The influence of dissolved gasoline components on MTBE and TBA degradation in Palo Alto sediments. The starting BTEX concentration was $\sim 1 \mathrm{mg} / \mathrm{L}$, which was completely degraded after 2 days.

no effect of gasoline components on MTBE degradation and no accumulation of TBA was observed in either case (data not shown). These results were consistent with previous exposure to dissolved gasoline components (Table 1). The Palo Alto sediments were taken from a distal portion of the MTBE plume that had not been exposed to other gasoline compounds, whereas, Travis AFB and San Mateo had experienced relatively high BTEX exposures, suggesting that microbial populations had become acclimated to gasoline components. 
The effect of dissolved gasoline components on microbial community structure was evaluated by DGGE analysis. For Travis AFB sediments, DGGE profiles were consistent with MTBE degradation results. The DGGE profiles were similar between microcosms exposed to MTBE only or to MTBE with gasoline components (Figure 4), suggesting that there was no effect of gasoline components on the presence of specific microorganisms. However, there did appear to be a band (marked by arrow) that was unique to microcosms with MTBE exposure and not present in other microcosm samples (i.e., microcosms exposed to gasoline components only). The sequence of this band most closely matched that of Aquabacterium sp. (99\% similar) and was 93\% similar with PM1 $16 \mathrm{~S}$ rDNA sequence. DGGE and real-time PCR analysis of microbial communities from Palo Alto sediments exposed to MTBE and/or gasoline components are ongoing.

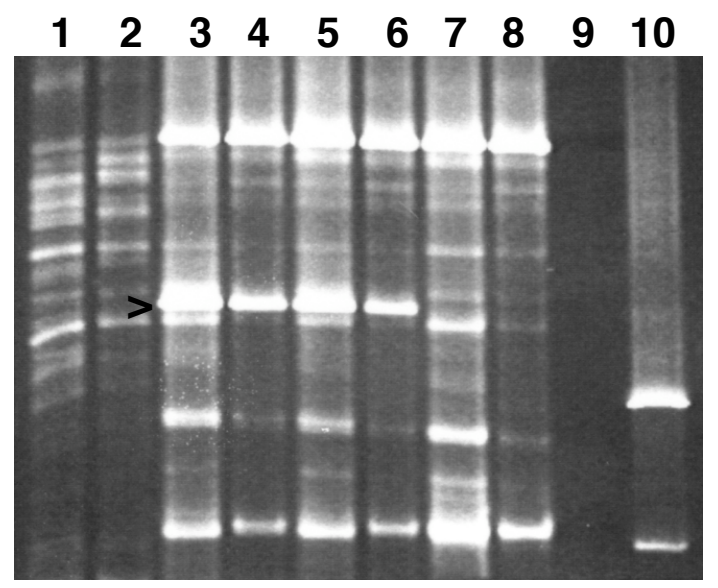

FIGURE 4. DGGE profiles of Travis AFB microcosms. Lanes 1 and 2, sterile controls; Lanes 3 and 4, MTBE exposure only; Lanes 5 and 6, MTBE and gasoline exposure; Lanes 7 and 8, gasoline exposure only; Lane 9, no-template control; and Lane 10, DGGE PCR positive control. The arrow denotes bands that were specific to MTBE-exposed microcosms (no corresponding band was present in microcosms with only dissolved gasoline component exposure).

\section{CONCLUSIONS}

Our results suggest that generalizations about the effect of oxygen and dissolved gasoline components on MTBE degradation cannot be made; simply adding oxygen to anoxic sediments does not always result in aerobic MTBE degradation, and water-soluble gasoline components inhibit MTBE and TBA degradation in some sediments and not in others. However, for this small sample set $(n=3)$, there was a correlation between MTBE inhibition in the presence of gasoline components and no prior exposure to gasoline components. Furthermore, our data showed that TBA, a known carcinogen, may accumulate and persist in some cases even with relatively low concentrations of MTBE; TBA accumulation was noted in the presence of dissolved gasoline components (Figure 3 ) as well as upon repeat additions of MTBE (Figure 1).

While microcosm studies are often a reliable means of predicting the potential for in situ MTBE biodegradation at LUFT sites, molecular phylogenetic analyses may serve as more rapid and powerful diagnostic tools. Real-time PCR methods are more sensitive than DGGE for these phylogenetic analyses, such that enrichment on MTBE would not be required for detection of strains capable of MTBE degradation. Further research is needed to confirm the apparent correlation between presence of Rubrivivax spp. related to strain PM1 and MTBE degradation activity suggested by this study. In depth analysis of pure culture MTBE degrading isolates is ongoing through a collaboration with UC-Davis, and funding support for our joint research project is being solicited. 


\section{ACKNOWLEDGMENTS}

We thank ChevronTexaco, Exxon Mobil Corp., M. Peterson (ETIC Engineering, Walnut Creek, CA) and W. Day (Travis AFB, CA) for supplying LUFT site data and aquifer materials. We acknowledge K. Hristova (University of California-Davis) for real-time PCR analysis, H. Pinkart (Central Washington University) for assistance with DGGE, and T. Alfaro (LLNL) for technical assistance, and H. Beller (LLNL) for helpful comments. This work was supported by Lawrence Livermore National Laboratory LDRD funding, andperformed under the auspices of the U.S. Department of Energy by University of California Lawrence Livermore National Laboratory (Contract No. W7405-Eng-48).

\section{REFERENCES}

Ausubel, F.M., R. Brent, R.E. Kingston, D.D. Moore, J.G. Seidman, J.S. Smith and K. Struhl. 1989. Current protocols in molecular biology. John Wiley \& Sons, New York, N.Y.

Beller, H. R., S. R. Kane, T. C. Legler, and P. J. J. Alvarez. 2002. A real-time polymerase chain reaction method for monitoring anaerobic, hydrocarbon-degrading bacteria based on a catabolic gene. Environ. Sci. Technol. 36:3977-3984.

Deeb, R. A., H. Y. Hu, J. R. Hanson, K. M. Scow, and L. Alvarez-Cohen. 2001. Substrate interactions in BTEX and MTBE mixtures by an MTBE-degrading isolate. Environ. Sci. Technol. 35:312-317.

Hanson, J. R., C. E. Ackerman, and K. M. Scow. 1999. Biodegradation of methyl tertbutyl ether by a bacterial pure culture. Appl. Environ. Microbiol. 65:4788-4792.

Happel, A. M., B. Dooher, and E. H. Beckenbach. 1998. Methyl tertiary butyl ether (MTBE) impacts to California groundwater. UCRL-AR-130897. Lawrence Livermore National Laboratory, University of California, Livermore, CA.

Hristova, K. R., C. M. Lutenegger, and K. M. Scow. 2001. Detection and quantification of methyl tert-butyl ether-degrading strain PM1 by real-time TaqMan PCR. Appl.

Environ. Microbiol. 67: 5154-5160.

Johnson, R., J. Pankow, D. Bender, C. Price, and J. Zogorski. 2000. MTBE: To what extent will past releases contaminate community water supply wells? Environ. Sci. Technol. 34:210A-217A.

Kane, S.R., H. R. Beller, T. C. Legler, C. J. Koester, H. C. Pinkart, R. U. Halden, and A. M. Happel. 2001. Aerobic biodegradation of methyl tert-butyl ether by aquifer bacteria from leaking underground storage tank sites. Appl. Environ. Microbiol. 67:5824-5829. UCRL-JC-143865.

Lane, D.J. 1991. 16S/23S rRNA sequencing, p.115-175. In E. Stackebrandt and M. Goodfellow (ed.), Nucleic acid techniques in bacterial systematics. John Wiley \& Sons, Inc., Chichester, United Kingdom.

Muyzer, G., E. C. de Waal, and A. G. Uitterlinden. 1993. Profiling of complex microbial populations by denaturing gradient gel electrophoresis analysis of polymerase chain reaction-amplified genes coding for 16S rRNA. Appl. Environ. Microbiol. 59:695-700. 
Salanitro, J. P., P. C. Johnson, G. E. Spinnler, P. M. Maner, H. L. Wisniewski and C. Bruce. 2000. Field-scale demonstration of enhanced MTBE bioremediation through aquifer bioaugmentation and oxygenation. Environ. Sci. Technol. 34:4152-4162.

Weisburg, W. G., S. M. Barns, D. A. Pelletier, and D. J. Lane. 1991. 16S Ribosomal DNA amplification for phylogenetic study. J. Bacteriol. 173:697-703.

Widdel, F., and F. Bak. 1992. Gram-negative mesophilic sulfate-reducing bacteria, p. 3352-3378. In A. Balows, H. G. Trüper, M. Dworkin, W. Harder, and K.-H. Schleifer (ed.), The prokaryotes. Springer-Verlag, New York.

Wilson, R. D., D. M. Mackay, and K. M. Scow. 2002. In situ MTBE biodegradation supported by diffusive oxygen release. Environ. Sci. Technol. 36: 190-1. 
